\title{
MODEL KESEHATAN KESELAMATAN KERJA BERBASIS AGRICULTURAL NURSING: STUDI ANALISIS MASALAH KESEHATAN PETANI
}

\section{(Occupational Health Nursing Model-Based Agricultural Nursing: A Study Analyzes of Farmers Health Problem)}

\author{
Tantut Susanto*, Retno Purwandari**, Emi Wuri Wuryaningsih*** \\ *Departemen Keperawatan Keluarga dan Komunitas, PSIK Universitas Jember. \\ *** Departemen Keperawatan Dasar dan Manajemen Keperawatan, PSIK Universitas Jember. \\ ${ }^{* * * *)}$ Departemen Keperawatan Jiwa, PSIK Universitas Jember. \\ Email: tantut_s.psik@unej.ac.id
}

\begin{abstract}
ABSTRAK
Pendahuluan: Mayoritas tenaga kerja Indonesia di daerah pedesaan bekerja di sektor pertanian yang berisiko untuk masalah kesehatan yang berkaitan dengan interaksi petani dan lingkungan. Hal ini diperlukan untuk mendekati keselamatan kesehatan berdasarkan pada perawatan kesehatan primer untuk mencegah dan mengurangi risiko kecelakaan atau penyakit. Studi ini mengidentifikasi masalah kesehatan petani dan faktor mereka untuk mengembangkan kerja keperawatan pertanian berbasis model keperawatan kesehatan di daerah pedesaan Jember. Metode: Penelitian cross-sectional dari 169 petani dilakukan untuk menyelidiki sosiodemografi, gaya hidup, lingkungan hidup dan bekerja, status kesehatan dan masalah kesehatan. Data yang dikumpulkan oleh kuesioner diberikan diri, penilaian fisik, dan tes darah. Analisis deskriptif dan komparatif meliputi tes chi-square dan analisis regresi ogistic dan multinomial digunakan untuk menilai hubungan antara faktor kehadiran masalah kesehatan. Hasil: Ada perbedaan antara sosiodemografi, lingkungan hidup dan bekerja dan masalah kesehatan petani ( $p$ $<0,05)$. Hampir 37,9\% dari petani adalah penyakit. Di antara 28,5\% dari berat badan dan 9,5\% dari kelebihan berat badan yang berhubungan dengan usia, minum kopi, dan kelebihan seharian bekerja. 62,6\% dari anemia yang berhubungan dengan gender dan kebiasaan merokok. Sementara itu, 45,2\% hipertensi sistolik dan 35,8\% hipertensi diastolik yang disebabkan oleh bekerja overload. Selanjutnya, 50,3\% dari nyeri pada bergabung dan tulang yang berhubungan dengan usia dan reses bekerja. Diskusi: Masalah kesehatan petani ditandai masalah gizi, anemia, hipertensi, dan rasa sakit yang terkait dengan lingkungan sosiodemografi biologis, psikologis, dan bekerja. Model keperawatan pertanian bisa mengembangkan untuk assessesment faktor terkait yang dirumuskan diagnosa masalah kesehatan pada petani di daerah pedesaan.
\end{abstract}

Kata kunci: keperawatan pertanian; keperawatan kesehatan kerja; petani; masalah kesehatan

\begin{abstract}
Introduction: The majority of Indonesian labor force at rural area works in the agricultural sector that risk for health problems related to interaction of farmer and environment. It is necessary to approach health care safety based on primary health care for to prevent and reduce the risks of accidents or illness. This study identifies farmer's health problem and their factors for developing occupational health nursing model-based agricultural nursing at rural area of Jember. Methods: A cross-sectional study of 169 farmers was done to investigate sociodemographic, lifestyles, environment of living and worked, health status and health problem. Data collected by the self administered questionnaire, physical assessment, and blood test. The descriptive and comparative analyses include chi-square tests and ogistic and multinomial regression analyses were used to assess the relationships between factors to the presence of health problems. Results: There was differences between sociodemographic, environment of living and worked and the health problems of farmers ( $p<0.05)$. Almost $37.9 \%$ of farmers is illness. Among $28.5 \%$ of underweight and $9.5 \%$ of overweight that related to age, drink of coffe, and excess day of work. $62.6 \%$ of anemia that related to gender and smoking habit. Meanwhile, $45.2 \%$ of sistolic hypertension and 35.8\% diastolic hypertension that caused by worked of overload. Furthermore, $50.3 \%$ of pain on join and bone related to age and recess of worked. Discussion: The health problems of farmers was characterized of nutritional problem, anemia, hypertension, and pain that related to sociodemographic environment of biologic, psychologic, and worked. Agricultural nursing model could be develop for assessesment of related factors that formulated diagnoses of health problems on farmers at rural area.
\end{abstract}

Keywords: agricultural nursing; occupational health nursing; farmer; health problem

\section{PENDAHULUAN}

Hasil survei BPS Kabupaten Jember dominasi penggunaan lahan adalah kegiatan pertanian yakni seluas 5.099,283 $\mathrm{Ha}$ atau $51,47 \%$ dari total luas wilayah (Badan Pusat Statistik, 2014). Pertanian dilihat sebagai suatu yang potensial dalam kontribusinya terhadap perekonomian di Indonesia dan juga dinilai dapat memiliki berbagai macam resiko kesehatan dalam pelaksanaan, hal tersebut dikarenakan pekerjaan petani masih belum memiliki standart Keselamatan dan Kesehatan Kerja (K3).

Laporan International Labor Organitation (ILO), 6.000 kasus K3 fatal terjadi setiap harinya dan setiap 100.000 tenaga kerja terdapat 20 orang terkena kasus K3 fatal di Indonesia. Kerugian yang harus ditanggung akibat kecelakaan 
kerja di negara berkembang mencapai $4 \%$ dari Gross National Product (GNP) (Depnakertrans, 2012). Sementara itu, rata-rata 2,2 juta orang meninggal per tahun akibat sakit atau kecelakaan yang berkaitan dengan pekerjaan mereka (Suardi, 2005).

Pekerja sektor informal di Indonesia dilaporkan terkena berbagai masalah kesehatan seperti malnutrisi, penyakit akibat parasit (misalnya cacingan), asma, alergi kulit, kanker, keracunan bahan kimia, keracunan makanan, gangguan otot dan tulang, gangguan saluran pernafasan, penyakit kelenjar getah bening, dan penyakit darah. Risiko bahaya yang dihadapi di tempat kerja antara lain meliputi kebisingan, vibrasi, radiasi panas, kurangnya pencahayaan, pemasangan alat berbahaya tanpa menggunakan Alat Perlindungan Diri (APD) untuk aspek keselamatan, menghirup debu dan terkena bahan kimia berbahaya, serta ergonomik yang buruk (Markkanen, 2004).

K3 dinilai dapat mengurangi resiko munculnya Penyakit Akibat Kerja (PAK). Program K3 di terapkan dalam bentuk Unit Kesehatan Kerja (UKK) di setiap puskesmas (Zaenal, et al., 2008) dengan mengenali hal-hal yang berpotensi menimbulkan kecelakaan dan penyakit akibat kerja serta tindakan antisipatif terjadinya kecelakaan dan penyakit akibat kerja (Lestari, 2007). Pendekatan Perawatan Kesehatan dan Keselamatan Kerja (PK3) berbasis agricultural nursing di puskesmas bertujuan untuk peningkatan pelayanan kesehatan kerja untuk lebih diarahkan pada partisipasi masyarakat. Pendekatan ini diharapkan dapat memenuhi kebutuhan untuk membentuk atau mendirikan unit perawatan kesehatan primer dalam masyarakat melalui pelayanan kesehatan yang bersifat promotif, preventif, kuratif dan rehabilitatif melalui pendekatan asuhan keperawatan di komunitas dengan pendekatan pada kelompok khusus pekerja. Berdasarkan paparan tersebut diatas, penelitian ini bertujuan untuk: 1) mengidentifikasi faktor-faktor yang mengakibatkan masalah kesehatan petani; 2) mengidentifikasi prevalensi masalah kesehatan petani; dan 3) menyusun model perawatan kesehatan keselamatan kerja berbasis agricultural nursing yang difokuskan pada pengkajian faktor dan masalah kesehatan di area rural Kabupaten Jember.

\section{BAHAN DAN METODE}

Penelitian ini menggunakan desain studi cross-sectional pada 169 petani di dua wilayah kerja puskesmas dengan dominasi sektor pertanian di daerah rural yang menerapkan UKK dengan binaan kelompok tani di Kabupaten Jember. Penelitian ini berlangsung selama 3 bulan (Juni-Agustus 2015). Sampel diambil secara multi stage random sampling. Penelitian ini merupakan penelitian multi tahun, dimana pada tahun pertema ini peneliti berfokus pada identifikasi faktor dan masalah sehingga dapat dirancang model perawatan K3 dengan menekankan pada pengkajian dan masalah. Data penelitian dikur dengan menggunakan kuesioner untuk mengukur setiap variabel yang mempengaruhi permasalahan kesehatan petani dan masalah penyakit yang ditimbulkannya.

Data sosial demografi (umur, jenis kelamin, suku, dan pendidikan), gaya hidup (merokok, minum kopi, dan makanan berlemak), lingkungan tempat tinggal (kondisi rumah, ventilasi dan sirkulasi, keadaan air, MCK, dan lingkungan sekitar), lingkungan psikologis (lama tinggal dan kenyamanan tinggal), dan lingkungan dan keadaan di tempat kerja petani (lama kerja, istirahat, hari kerja, beban kerja, APD, posisi kerja atau ergonomis) diukur dengan menggunakan kuesioner.

Status sehat sakit diukur dengan melakukan pengkajian fisik langsung. Masalah kesehatan terkait status nutrisi diukur melalui tinggi badan $\left(\mathrm{m}^{2}\right)$ dan berat badan $(\mathrm{kg})$ dengan menggunakan timbangan digital dari Omron yang kemudian dikonversi menjadi indeks masa tubuh (IMT). Hasil IMT diklasifikasikan untuk menentukan status nutrisi (underweight: IMT kurang dari 18.5; Normal: IMT 18.5-24.9; Overweight: IMT 25-27; dan Obesity: IMT lebih dari 27; kemudian, overweight and obesity dikelompokkan menjadi satu yaitu overweight.

Pengukuran tekanan darah dilakukan untuk mengidentifikasi hipertensi baik sistolik dan diastolik dengan menggunakan tensi meter air raksa dari Omron. Pengukuran tekanan darah sistolik dan diatolik (mmHg) dikategorikan berdasarkan JNC VII untuk menentukan status hipertensi, yaitu: Hipertensi Sistolik (normal <120 mmHg; pre hipertensi 120-139 mmHg; hipertensi stage I $140-159 \mathrm{mmHg}$ dan hipertensi stage II $>160 \mathrm{mmHg}$ ). Hipertensi diastolik (normal < $80 \mathrm{mmHg}$; pre hipertensi $80-89 \mathrm{mmHg}$; hipertensi stage I $90-99 \mathrm{mmHg}$ dan hipertensi stage II >100 $\mathrm{mmHg}$ ).

Pengukuran kadar $\mathrm{Hb}$ dilakukan untuk mengetahui status anemia diukur dengan 
Hemocue. Anemia dikategorikan berdasarkan hasil pegukuran kadar $\mathrm{Hb}$ (Anemia: Hb kurang dari $12 \mathrm{gr} / \mathrm{dl}$ dan normal jika Hb lebih dari 12 $\mathrm{gr} / \mathrm{dl})$. Pemeriksaan fisik sendi dan tulang ekstremitas atas dan bawah serta tulang belakang dilakukan untuk mengetahui nyeri tulang dan sendi. Hasil pengukuran dikategorikan nyeri apabila mengalami keluhan nyeri pada tulang dan sendi kurang lebih 1 minggu terakhir atau tidak.

Peralatan pengukuran berat badan dan tinggi badan, tekanan darah, dan kadar $\mathrm{Hb}$ telah dilakukan uji kalibrasi terlebih dahulu sebelum digunakan. Adapun kriteria sampel penelitian ini adalah petani yang berusia lebih dari 17 tahun, bekerja sebagai petani minimal satu tahun di wilayah kerja puskesmas penelitian berlangsung dan terdaftar sebagai anggota kelompok tani serta bersedia menjadi responden. Prosedur pengumpulan data dilakukan dengan terlebih dahulu menjelaskan tujuan penelitian kepada partisipan dan dilanjutkan dengan pemberian inform consent apabila bersedia menjadi partisipan.

Pengambilan data dilakukan di balai kelompok tani di lingkungan terdekat partisipan. Setelah responden bersedia kemudian diberikan kuesioner untuk responden isi terkait dengan data sosial demografi, gaya hidup, karakteristik lingkungan tempat tinggal dan lingkungan pekerjaan. Setelah responden selesai mengisi kuesioner dilakukan pemeriksaan fisik, dan pengukuran tinggi badan dan berat badan, tekanan darah, dan kadar $\mathrm{Hb}$ di rungan pemeriksaan yang telah disiapkan oleh peneliti. Pengambilan data dari awal sampai selesai dibutuhkan waktu kurang lebih 30 menit untuk setiap responden. Dalam penelitian ini telah mendapatkan ijin dari Lembaga Penelitian Universitas Jember dan Dinas Kesehatan Kabupaten Jember dengan tetap mempertahankan prinsip etika penelitian terkait dengan kejujuran, kerahasiaan, dan keteradilan, dan kemanfaatan penelitian.

Data dianalisis secara univariat, bivariat, dan multivariat. Analisis univariat berupa statistik deskriptif, seperti frekuensi dan prosentase digunakan untuk menganalisis data kategorik, sedangkan mean dan standard deviasi digunakan untuk menganalisis data kontinyu, sehingga dapat diketahui prevalensi masalah kesehatan petani. Analisis bivariat berupa analisis comparatif digunakan uji chisquare tests dalam mengidentifikasi variabel yang berhubungan dengan kesehatan petani. Analisis multivariat digunakan analisis regersi logistik dan multinomial untuk menggambarkan model perawatan kesehatan kerja (pengkajian dan diagnosis atau masalah kesehatan).

\section{HASIL}

Berdasarkan hasil penelitian didapatkan data prevalensi masalah kesehatan beserta dengan faktor-faktor yang berhubungan dengan munculnya masalah kesehatan. Petani yang mengalami gizi kurus adalah $28.5 \%$ dengan karakteristik usia lebih dari 60 tahun (43.1\%) dan mengkonsumsi kopi (60.8\%) yang berhubungan dengan jumlah hari kerja yang lebih dari lima hari per minggu (58.8\%) dan karakteristik lingkungan fisik yang tidak sehat. Petani yang mengalami gizi lebih adalah $9.5 \%$ dengan usia 41-59 tahun (58.8\%) yang berhubungan dengan jumlah hari kerja yang kurang dari 5 hari per minggunya $(76.5 \%)$.

Petani yang mengalami anemia adalah $62.6 \%$ dengan jenis kelamin laki-laki (81.3\%) dan merokok (46.8\%) yang berhubungan dengan jumlah hari kerja yang lebih dari 5 hari per minggu $(64.3 \%)$ dan posisi atau sikap kerja yang tidak ergonomi (57.1\%). Permasalahan tekanan darah atau hipertensi sistolik adalah pre hipertensi sistolik (20.1\%) dan hipertensi sistolik grade 1 dan 2 (25.1) serta hipertensi diastolik grade 1 dan 2 (35.8\%) yang berkaitan dengan gaya hidup merokok (55.6\%), makanan berlemak (55.6\%) dan tinggi garam (60\%) serta berhubungan dengan beban atau stress kerja $(58.3 \%)$ dan tidak menggunakan APD (64.4\%).

Petani yang mengalami nyeri persendian dan tulang sebanyak $50.3 \%$ yang berhubungan dengan usia antara 41-59 tahun (44.4\%), istirahat kerja yang kurang dari 30 menit tiap bekerja $(70 \%)$ dan posisi kerja yang tidak ergonomis $(54.4 \%)$. Petani yang mengalami sakit sebesar 39.7\% dengan karakteristik tidak bersekolah (53.5\%) dan merokok (56.3\%) serta berhubungan dengan lingkungan kerja seperti stress kerja (57.7\%) dan lingkungan tempat tinggal yang tidak sehat, seperti kualitas air minum yang tidak sehat $(88.7 \%)$.

Didapatkan data bahwa faktor risiko dan faktor pencegah masalah gizi kurang dan lebih, anemia, nyeri tulang dan sendi, serta status sakit pada petani. Hasil regresi multonominal (status gizi normal sebagai reference) memperlihatkan bahwa petani yang berusia lebih dari 60 tahun berisiko 3.57 kali (1:0.28) dan yang berusia $40-60$ tahun berisiko 4 kali (1:0.25) serta mengkonsumsi kopi berisiko 
2.78 kali (1:0.36) untuk mengalami gizi kurus. Sementara itu, petani yang beristirahat lebih dari 30 menit setiap bekerja berisiko 14.28 kali (1:0.07) dan bekerja kurang dari 5 hari per minggu berisiko 16.67 kali (1:0.06) mengalami gizi lebih.

Hasil regersi logistik menunjukkan bahwa Petani yang berusia 40-60 tahun berisiko 0.39 dan berjenis kelamin laki-laki berisiko 0.10 lebih rendah mengalami anemia. Model ini memprediksi sebesar $68.2 \%$ untuk terjadinya anemia padapetani. Tabel 3 juga memperlihatkan bahwa petani yang berusia lebih dari 60 tahun berisiko 2.48 dan yang berusia 40-60 tahun berisiko 2.41 serta yang beristirahat kuran dari 30 menit selama bekerja akan mengalami nyeri sendi dan tulang. Model ini memprediksi sebesar $63.7 \%$ petani untuk mengalami nyeri sendi dan tulang. Selain itu, petani akan berisiko mengalami permasalahan kesehatan atau status kesehatan sakit sebesar 4 kali pada petani yang tidak sekolah tetapi hal ini dapat dicegah apabila petani tidak mengalami stress kerja maka akan berisiko sebesar 0.54 kali lebih rendah untuk mengalami sakit.

Model perawatan kesehatan kesalamatan kerja berbasis agricultural nursing yang merupakan sintesis dari Model tersebut menunjukkan komponen pengkajian dan masalah kesehatan (diagnosis masalah) petani. Pengkajian digambarkan adanya fakor-faktor yang mempengaruhi sehat-sakit petani, kemudian masalah kesehatan digambarkan dengan munculnya masalah gizi (kurus dan lebih), anemia, hipertensi, nyeri tulang dan sendi. Masalah petani tersebut digambarkan dengan adanya karakteristik penyebab yang berhubungan dengan munculnya permasalahan, baik pada faktor sosioal demografi, gaya hidup, lingkungan kerja, dan lingkungan tempat tinggal.

\section{PEMBAHASAN}

Penelitian ini menganalisis faktor-faktor yang mempengaruhi kesehatan petani dan kemudian mencoba menyusun suatu model perawatan kesehatan dan kesalamatan kerja berbasis agricultural nursing. Hasil penelitian menunjukkan bahwa banyak faktor yang mempengaruhi kesehatan petani sehingga mengakibatkan masalah gizi, anemia, hipertensi, dan nyeri pada tulang dan persendian. Prevalensi gizi kurang pada penelitian ini lebih tinggi bila dibandingkan dengan angka nasional yaitu $8.7 \%$ (Ministry of Health Indonesia, 2013). Hal ini berkaitan dengan usia lanjut (KS \& TY, 2004) pada petani dan riwayat mengkonsumsi kopi (Susanti, et al., 2011) yang akan mempengaruhi penyerapan makanan didalam lambung sehingga memicu terjadinya gizi kurang. Masalah kesehatan lingkungan dan sanitasi juga mengakibatkan masalah gizi kurang pada petani, hal tersebut revelan dengan studi bahwa agen bakteri dan virus pada lingkungan akan berpengaruh masalah kecacingan yang berdampak pada gizi kurang (Markkanen, 2004). Hal ini sangat menggambarkan keadaan daerah rural pertanian di Indonesia yang mengalami masalah gizi kurang akibat kesenjangan standar hidup, keadaan sosial ekonomi, dan gaya hidup yang akan memnegaruhi kesehatan petani.

Masalah gizi lebih padapenelitian ini lebih rendah dari angka nasional yaitu gizi lebih $13.5 \%$ dan obesitas $15.4 \%$ (Ministry of Health Indonesia, 2013). Petani yang mengalami gizi lebih dikarenakan kurangnya jumlah hari kerja tiap minggunya. Permasalahan gizi lebih umumnya berkaitan dengan kurangnya aktivitas fisik dan akan berdampak pada penyakit kronis (Silva, et al., 2014). Petani lebih berisiko mengalami gizi kurang daripada gizi lebih yang menggambarkan tingginya jam kerja yang tidak diimbangi dengan peningkatan konsumsi nutrisi pada petani di daerah rural. Hal ini akan berdampak pada produktivitas kerja petani (Jurakic, et al., 2014) dan mengarah pada status sehat sakit petani.

Petani berjenis kelamin laki-laki dan memiliki riwayat merokok berisiko untuk mengalami anemia. Hal ini sesuai dengan riset sebelumnya bahwa, lelaki berisiko menderita masalah kesehatan akibat tuntutan sosial ekonomi (Kaleta, et al., 2012), Prevalensi anemia pada petani dalam penelitian ini lebih tinggi dari angka nasional yaitu 20\% (Ministry of Health Indonesia, 2013). Kondisi anaemia defisiensi zat besi dalam penelitian ini diakibatkan karena faktor merokok dan beban kerja yang terlalu tinggi, hal ini mengakibatkan penurunan ikatan oksigen dan $\mathrm{Fe}$ karena adanya zat rokok didalam darah sehingga mengganggu transpor oksigen dalam darah kemudian berdampak pada kelelelahan yang muncul pada petani dan ditunjang dengan beban kerja petani yang terlalu tinggi. 
Petani yang berusia lebih tua mengalami nyeri sendi dan tulang, karena pada masa lansia umumnya muncul penyakit metabolik degeneratif yang ditandai dengan berkurangnya massa tulang dan risiko patah tulang yang mengakibatkan hilangnya mobilitas sendi (Rafiah, et al., 2014). Hal ini relevan dengan studi sebelumnya bahwa pekerja di pertambangan menderita sakit terutama di punggung bawah, tangan, lutut, pergelangan tangan, bahu, dan leher (Das, 2014). Masalah nyeri sendi pada petani diakibatkan posisi kerja yang tidak ergonomis dan masa istirahat dalam berkerja yang terlalu singkat (Tella, et al., 2013), karena petani bekerja dari pagi sampai malam tanpa waktu yang cukup untuk mengambil waktu istirahat akan mengakibatkan nyeri pada tulang dan sendi akibat penggunaan dan pemakaian masa otot dan tulang yang melebihi dari kapasitas kerja. Hal ini akan mengakibatkan nyeri punggung bawah setelah melebihi dari beban kerja (Gupta \& Nandini, 2015).

Permasalahan hipertensi pada petani teridentifikasi pada petani dengan gaya hidup yang tidak sehat, seperti merokok, mengkonsumsi makanan tinggi lemak dan garam. Hal ini sesuai dengan dengan riset sebelumnya bahwa empat faktor risiko terjadinya non communicabel diseases adalah merokok, konsumsi alkohol, aktivitas fisik yang tidak memadai dan diet yang tidak sehat (Low, et al., 2015). Masalah hipertensi pada petani juga berhubungan dengan beban kerja dan stress kerja, dimana makin besar stress kerja akan menunjang tingkat kematian pada pekerja yang sudah berusia lanjut (Tobiasz-Adamczyk, et al., 2013). Hal ini dikarenakan stress kerja dan beban kerja pada petani yang tinggi akibat tuntutan pekerjaan dalam produktivitas pertanian dari bercocok tanam, memanen, dan menjual hasil pertanian mengakibatkan sistem cardiorespirasi bekerja lebih tinggi sehingga akan berdampak pada kenaikan tekanan darah. Sementara itu, pola hidup yang tidak sehat, seperti merokok dan makanan berlemak akan memicu terjadinya resistensi tahanan perifer dan berdampak pada kenaikan tekanan darah.

Faktor risiko utama status kesehatan petani yang sakit adalah pendidikan petani yang tidak sekolah. Hal ini berkaitan dengan rendahnya pengetahuan dan pemahaman petani terhadap program ketrampilan hidup sehat (PKHS). Karakteristik umum dari kondisi sakit dalam penelitian ini ditandai dengan lingkungan sanitasi tempat tinggal yang tidak sehat seperti tipe rumah yang tidak permanen, ventilasi dan pencahayaan rumah, manajemen sampah dan MCK, serta kualitas air minum yang tidak sehat. Hal ini berkaitan dengan lingkungan sebagai media vektor penyakit yang akan berdampak baik secara langsung maupun tidak langsung terhadap masalah kesehatan dan promosi kesehatan individu, kelompok, dan komunitas (Pender, et al., 2014). Hal ini memerlukan perhatian antara keseimbangan faktor petani, agen, lingkungan dan kesehatan dalam mencegah masalah kesehatan pada petani.

\section{SIMPULAN DAN SARAN}

\section{Simpulan}

Model perawatan kesehatan dan keselamatan kerja berbasis agricultural nursing yang disusun dalam penelitian ini dikembangkan berdasarkan analisis faktor sosial demografi, gaya hidup, faktor lingkungan fisik, psikososial, dan lingkungan kerja yang disusun menjadi karakteristik untuk diidentifikasi dalam pengkajian keperawatan komunitas pada kelompok petani. Masalah kesehatan yang teridentifikasi beserta faktor penyebabnya dapat menjadi diagnosis atau masalah kesehatan kerja pada petani.

\section{Saran}

Penelitian berikutnya perlu dilakukan uji coba model dengan melakukan beberapa intervensi keperawatan mandiri dan terapi modalitas kelompok sehingga dampak dari penerapan model perawatan kesehatan kesalamatan kerja berbasis agricultural nursing ini dapat dievaluasi.

\section{KEPUSTAKAAN}

Badan Pusat Statistik, 2014. Berita Resmi Statistik No. 33/05/Th.XV.7 Mei 2012. [Online].

Das, B., 2014. Assessment of Occupational Health Problems and Physiological Stress Among The Brick Field Workers of West Bengal, India. International Journal of Occupational Medicine and Environmental Health, 27(3), pp. 413425.

Depnakertrans, 2012. Pusat data dan Informasi Ketenagakerjaan Badan Penelitian, Pengembangan, dan 
Informasi Kementrian Tenaga Kerja

Dan Transmigrasi RI. [Online] Available at: http://pusdatinaker.go.id [Accessed 2014].

Gupta, G. \& Nandini, N., 2015. Prevalence of Low Back Pain in Non Working Rural Housewives of Kanpur, India. International Journal of Occupational Medicine and Environmental Health, 28(2), pp. 313-320.

Jurakic, D., Golubic, A., Pedisic, Z. \& Pori, M., 2014. Patterns and Correlates of Physical Activity Among Middle-Aged Employees: A Population-Based, Crosssectional Study. International Journal of Occupational Medicine and Environmental Health, Volume 3, pp. 487-497.

Kaleta, D., Makowiec-Dabrowska, T., Dziankowska-Zaborszczyk, E. \& Fronczak, A., 2012. Prevalence and Socio-Demographic Correlated of Daily Cigarette Smoking in Poland: Results From The Global Adults Tobacco Survey (2009-2010). International Journal of Occupational Medicine and Environmental Health, 25(2), pp. 126136.

KS, Y. \& TY, L., 2004. Sociodemographic Factors Associated with Nutrients Intake of Elderly in Korea. Korean Journal Nutrition, 37(3), pp. 210-222.

Lestari, T., 2007. Hubungan Keselamatan Dan Kesehatan Kerja (K3) Dengan Produktivitas Kerja Karyawan (Studi Kasus : Bagian Pengolahan Ptpn Viii Gunung Mas, Bogor). [Online] Available at: http://repository.ipb.ac.id/bitstream/hand le/123456789/17179/H07tle.pdf

[Accessed 2014].

Low, W.-Y., Lee, Y.-K. \& Samy, A. L., 2015. Non Communicable Diseases in The Asia-Pacific Region: Prevalence, Risk Factors, and Community Based Prevention. International Journal of Occupational Medicine and Environmental Health, 28(1), pp. 20-26.

Markkanen, P. K., 2004. Kesehatan dan Keselamatan Kerja di Indonesia (Health and Work Safety in Indonesia), Manila,
Philippines: Iternational Labour Organization, Subregional office for South-East Asia and the Pacific.

Ministry of Health Indonesia, 2013. Riset Kesehatan Dasar 2013/Riskesdas 2013 (Basic Health Research 2013), Jakarta: Badan Penelitian dan pengembangan Kesehatan.

Pender, N., Carolyn, L. \& Mary, A., 2014. Health Promotion in Nursing Practice. $7 r d$ edition. Stamford: Appleton \& Lange.

Rafiah, S., Rieuwpassa, I. E., Bahrun, U. \& Bahri, M., 2014. Low density lipoprotein sebagai faktor prediktor terhadap penurunan densitas mineral tulang pada osteoporosis. [Online].

Silva, F. C. D. et al., 2014. Anthropometric Indicators of Obesity In Policeman: A Systematic Review of Observational Study. International Journal of Occupational Medicine and Environmental Health, 27(6), pp. 891901.

Suardi, 2005. Sistem Manajemen Keselamatan Dan Kesehatan Kerja. Jakarta: PPM.

Susanti, A., Briawan, D. \& Urip, V., 2011. Dyspepsia Risk Factors of University Students in Bogor Agricultural University. Jurnal Kedokteran Indonesia, 2(1), pp. 80-91.

Tella, B. A., Sunday Rufus Akinwumi Akinbo, S. A. A. \& Gbiri, C. A., 2013. Prevalence and Impacts of Low Back Pain among Peasant Farmers in SouthWest Nigeria. International Journal of Occupational Medicine and Environmental Health, 26(4), pp. 621627.

Tobiasz-Adamczyk, B., Brzyski, P., Florek, M. \& Brzyska, M., 2013. Job Stress and Mortality in Older Age. International Journal of Occupational Medicine and Environmental Health, 26(3), p. 349 362.

Zaenal, A., Tri, W. \& Ishandono, D., 2008. Hubungan Perilaku Keselamatan Dan Kesehatan Kerja Dengan Dosis Radiasi Pada Pekerja Reaktor Kartini. Jurnal STT Batan, pp. 1-10. 